\title{
Is Iron Deficiency Anemia Associated with Cognitive Functions in Reproductive-Age Women?
}

\section{Demir Eksikliği Anemisi Üreme Çağındaki Kadınlarda Bilișsel Fonksiyonlarla İlișkili midir?}

\author{
Aslı Gençay Can¹, Serdar Süleyman Can², Murat İlhan Atagün², Emine Tuğçe Akçaer ${ }^{2}$ \\ 'Universitiy of Health Sciences, Diskapi Yildirim Beyazit Research and Training Hospital, \\ Department of Physical Medicine and Rehabilitation, Ankara \\ ${ }^{2}$ Ankara Yildirim Beyazit University Faculty of Medicine, Department of Psychiatry
}

\begin{abstract}
Objectives: The aim of the study was to determine whether iron deficiency anemia (IDA) affects cognitive functioning, physical functioning, psychiatric morbidity, fatigue and quality of life in reproductive-age women.

Materials and Methods: Thirty-three women aged between 18-50 years with IDA and 32 non-anemic healthy women were included in the study. Laboratory analyses, neuropsychological tests, Beck Depression Inventory (BDI), Beck Anxiety Inventory (BAI), VAS fatigue, Health Assessment Questionnaire (HAQ-DI) and Short Form-36 (SF-36) were assessed.

Results: There was no significant difference in demographic characteristics of the patients between groups. Digit Forward/Backward, Digit Span Total, HAQ-DI, BAI, BDI, SF-36, fatigue scores in IDA group were significantly lower than the controls. Correlation analysis revealed that education, serum iron, ferritin, and hemoglobin levels were associated with cognitive test scores and fatigue. Serum iron, ferritin, and hemoglobin levels were found to be associated with HAQ-DI, BAI, BDI, and SF-36 scores.

Conclusion: IDA negatively affects cognition, physical functioning, quality of life, fatigue, symptoms of anxiety and depression in reproductive-age women.

Key words: Iron deficiency anemia, reproductive-age women, cognition
\end{abstract}

\section{Öz}

Amaç: Bu çalışmanın amacı, üreme çağındaki kadınlarda demir eksikliği anemisinin bilişsel fonksiyonlar, fiziksel fonksiyonellik, psikiyatrik morbidite, yorgunluk ve yaşam kalitesi üzerindeki etkilerini incelemekti.

Materyal ve Metot: Yaşları 18-50 arasında değișen ve demir eksikliği anemisi olan 33 kadın ve anemisi olmayan 32 sağlıklı kadın çalıșmaya dahil edildi. Laboratuvar analizi, nöropsikolojik testler, Beck Depresyon Ölçeği, Beck Anksiyete Ölçeği, VAS yorgunluk, Sağlık Değerlendirme Anketi ve Kısa Form-36 değerlendirildi.

Bulgular: Gruplar arasında demografik özellikler açısından anlamlı fark saptanmadı. Demir eksikliği Anemisi olan grupta Digit Forward/Backward, Digit Span Total, Sağlık Değerlendirme Anketi, Beck Depresyon Ölçeği, Beck Anksiyete Ölçeği, Kısa Form-36 ve yorgunluk skorları kontrol grubuna gore anlamlı olarak daha düșüktü. Korelasyon analizinde eğitim, serum demir, ferritin ve hemoglobin düzeyleri ile bilișsel test skorları ve yorgunluk arasında anlamlı ilișkili bulundu. Serum demir, ferritin ve hemoglobin düzeyleri ile Sağlık Değerlendirme Anketi, Beck Depresyon Ölçeği, Beck Anksiyete Ölçeği ve Kısa Form-36 skorları arasında anlamlı ilișki bulundu.

Sonuç: Demir eksikliği anemisi üreme çağındaki kadınlarda bilişsel fonksiyonları, fiziksel fonksiyonelliği, yaşam kalitesini, yorgunluğu, anksiyete ve depresyon semptomlarını negative yönde etkilemektedir.

Anahtar kelimeler: Demir eksikliği anemisi, üreme çağındaki kadınlar, bilişsel fonksiyonlar

\section{Correspondence / Yazışma Adresi:}

Dr. Asli Gençay Can

Diskapi Yildirim Beyazit Research and Training Hospital, Department of Physical Medicine and

Rehabilitation, Ankara

e-mail: asligencay@yahoo.com

Date of submission: 05.10.2018, Date of admission: 14.12.2018 


\section{Introduction}

Iron deficiency (ID) is the most prevalent cause of anemia in both developing and developed countries affecting more than $50 \%$ of women of reproductive age. ${ }^{1}$ Iron deficiency manifests not only as anemia but also have negative effects on mental development, motor performance, cognitive and behavioural functions. ${ }^{2-4}$

Multiple studies showed that ID and IDA are directly related with various pathologies in the central nervous system including cognitive deficits. These effecs are marked at infancy and early childhood. The most affected functions involved in cognition are learning and memory. There are many different pathways which ID can affect cognition.3,4 Iron is essential for neurotransmitter synthesis and myelin formation in the cortex. ${ }^{4}$ Synthesis of neurotransmitters such as dopamine and norepinephrinein the hippocampus, striatum and cortex is a iron dependent pathway. Alterations of these neurotransmitters metabolism and decrement of D2 receptors in the brain are responsible for cognitive deficits. Animal studies have shown that ID is also related to demyelination of neurones. Long-term pathologic processmay be result in decreased conduction velocity and memory problems. ${ }^{3}$

There is a strong evidence that IDA during infancy and childhood negatively impacts neurodevelopment, learning capacity, attention, concentration and memory.4,5 However, only a few studies have evaluated relationship between IDA and cognitive performance in young adults. ${ }^{1,2,6,7}$ Women of reproductive age have a higher risk for IDA due to inadequate dietary intake, high menstrual loss and pregnancy. ${ }^{8}$ Because of these, it is important to reveal the effects of IDA on cognition in reproductive-age women.

Beside of cognitive dysfunction, IDA may be an important determinant of impaired physical functioning, decreased quality of life, anxiety, depression and fatigue.9,10 Some previous studies indicated thatdevelopment of depression, anxiety and fatigue may be related to the existence of IDA. As a consequence, health related quality of life in subjects with IDA may be affected negatively. On the other hand, the literature on fatigue, mental health and physical health is limited and results are controversial. ${ }^{11}$

The aim of the study was to determine whether IDA in reproductive-age women affects cognitive functioning, physical functioning, anxiety, depression, fatigue and quality of life.

\section{Materials and Methods}

Thirty-three women between the ages of 18-50 years with IDA were included in the study. All patients admitted to a physical medicine and rehabilitation outpatient clinic for arthralgia and/or myalgia. The criteria for inclusion of women in the study were age between 18-50 years with IDA, non-pregnant, no medical disease that may affect cognitive and physical function like endocrinological disease, neurological disease and vitamin B12/folate deficiency, no drug usage that may cause sedation during last 6 months, no iron treatment during last 6 months. Iron deficiency anemia was defined as $\mathrm{Hb}$ concentration less than $12 \mathrm{~g} / \mathrm{L}$ for women, a mean corpuscular volume less than 80 $\mathrm{fL}$, and a serum ferritin level less than $20 \mathrm{ng} / \mathrm{ml} .{ }^{11}$ Thirty-two non-anemic healthy women matched for age and education were included as a control group. This study 
was performed with the approval of the local ethics committee. All patients provided written informed consent to participate.

Laboratory analyses for complete blood count, serum iron and ferritin levels, total iron binding capacity, thyroid function tests, vitamin B12 and folate levels, liver and kidney function tests were performed in all participants. Neuropsychological tests, Beck Depression Inventory (BDI), Beck Anxiety Inventory (BAI), VAS fatigue, Health Assessment Questionnaire (HAQ-DI) and Short Form-36 (SF-36) were assessed in all participants.

Neuropsychological evaluation was carried out by an experienced psychiatrist using Digit Span (including Digit forward and Digit backward) and Digit Symbol tests. These tests are subunits of Weschler Intelligence Scale-III. Forward and backward Digit Span tests are used for short-term working memory. Digit Span is measured for forward and backward recall of digit sequences. Digit sequences continue by increasing the series of numbers. Testing ceases when the subject fails to accurately report either trial at one sequence length or when the maximal list length is reached (9 digits forward, 8 backward). The number of lists reported correctly in each test is recorded. The scores of Digit-forward and Digit-backward are combined to form Digit Span Total score. ${ }^{7}$ Digit Symbol test is mainly used toassessprocessing speed. It consists of 9-digit symbols matched with their corresponding numerical digit. It requires the patient to copy the symbols that are matched to each number as fast as possiblewithin the allowed time (90 seconds). ${ }^{12}$ Turkish validity and reliability of Weschler Intelligence Scale-III were made by Savasir et al. ${ }^{13}$

Health Assessment Questionnaire Disability Index (HAQ-DI) is widely used to measure physical function of both upper and lower extremities. It is a 20-item questionnaire with eight domains: dressing and grooming, arising, eating, walking, hygiene, reach, grip and activities. Each item is scored between o and 3. Higher score shows more disability. The validity and reliability of the Turkish version has been previously performed by Kucukdeveci et al. ${ }^{14}$

The quality of life ofstudy subjects was measured using the Short Form-36 (SF-36). It is a 36-item questionnaire with 8 domains measuring physical and mental health status (SF-36 PCS and SF-36 MCS, respectively). Each item is scored and summed according to a standardized scoring protocol and each domain is scored between o and 100. Higher scores indicate better health status. The validity and reliability of the Turkish version of the SF-36 has been done by Pinar. ${ }^{15}$

Depressive symptoms and anxiety of the subjects were assessed by Beck Depression Inventory (BDI) and Beck Anxiety Inventory (BAI), respectively. Both inventories are 21-item self-administered questionnaires. These provide a quantitative measure of depressive symptoms and anxiety symptoms. Each item was scored between o and 3 points. Higher scores indicate greater levels of anxiety and depression. The Turkish validity and reliability of the BDI has been performed by Hisli. ${ }^{16}$. The Turkish validity and reliability of the BAI has been done by Ulusoy et al. ${ }^{17}$

o-100 mm VAS was used to assess the fatigue of study subjects. Subjects were asked to mark the point corresponding to the fatigue during the past week. 


\section{Statistical Analysis}

Independent samples t-test and chi-square test were performed to compare the demographic and clinical characteristics between the two groups. Results are expressed as means \pm SD. Pearson's correlation analysis was performed to assess the contributions of education and laboratory parameters on cognitive functions, SF-36, HAQ-DI, BDI, BAI and fatigue. Pearson's correlation coefficients ( $\mathrm{r}$ ) were accepted as follows: $0.81-1.0$ as excellent, $0.61-0.80$ very good, $0.41-0.60$ good, $0.21-0.40$ fair, and o0.20 poor. ${ }^{18}$ SPSS version 17 (SPSS Inc., Chicago, IL, USA) was used for all statistical analyses. p-values less than 0.05 were considered to represent a significant difference.

\section{Results}

There was no significant difference in demographic characteristics of the patients between groups ( $\mathrm{p}>0.05$ ). The demographic characteristics and laboratory data of the groups have been shown in Table 1.

Scores of Digit Forward, Digit Backward and Digit Span Total in IDA group were significantly lower than the controls $(\mathrm{p}<\mathrm{o.oo1})$. Digit Symbol scores were lower in IDA group, but the difference did not reach the level of significance ( $p>0.05)$. HAQ-DI, BAI, BDI, SF-36 PCS and MCS, VAS fatigue scores were significantly impaired in IDA group (p<0.05) (Table 1).

In correlation analysis, education, hemoglobin, serum iron and serum ferritin levels have moderate to good positive correlations with scores of Digit Forward, Digit Backward and Digit Span ( $\mathrm{p}<0.05)$. While education and serum iron level were correlated positively with Digit Symbol score $(\mathrm{p}<0.05)$, there were no significant correlations between Digit Symbol score and levels of hemoglobin and serum ferritin (p>0.05) (Table 2).

Moderate negative correlations were detected between HAQ-DI scores and levels of serum iron, ferritin, and hemoglobin $(\mathrm{p}<0.05)$. No significant correlation was detected between HAQ-DI score and levels of education ( $\mathrm{p}>0.05$ ). Hemoglobin, serum iron and serum ferritin levels were moderately negatively correlated with scores of BAI and BDI scores $(\mathrm{p}<0.05)$. There was no significant correlation between education and scores of BAI and BDI ( $\mathrm{p}>0.05)$. Hemoglobin, serum iron and serum ferritin levels have moderate to good positive correlations with SF-36 PCS and MCS ( $\mathrm{p}<0.05)$. Education was not found to correlate significantly with SF-36 PCS and MCS (p>0.05). There were moderate to good negative correlations between levels of hemoglobin, serum iron and serum ferritin and fatigue VAS score $(\mathrm{p}<0.05)($ Table-3).

\section{Discussion}

Iron deficiency with and without anemia is one of the most important health problems among women of reproductive age. Iron is an important element for brain growth, myelination, neurotransmitter synthesis. ${ }^{19}$ As a consequence, IDA seems to be linked to motor and cognitive dysfunction and socio-emotional problems. ${ }^{4}$ Many studies on cognitive functioning and physical functioning have focused on infants and early childhood. ${ }^{4,5}$ Less research had focused on the effects of IDA in women of reproductive age., ${ }^{1,6}$ This study revealed that decreased serum iron, ferritin, and hemoglobin levels are associated with poorer cognitive and motor performance, increased anxiety and 
depressive symptoms, impaired quality of life and increased fatigue in women of reproductive age.

Table 1. Demographic and clinical characteristics of the subjects

\begin{tabular}{|c|c|c|c|}
\hline & $\begin{array}{l}\text { IDA group }(n=33) \\
(\text { mean } \pm \text { SD or } \%)\end{array}$ & $\begin{array}{c}\text { Control group }(n=32) \\
(\text { mean } \pm S D \text { or } \%)\end{array}$ & $\mathbf{p}$ \\
\hline Age (years) & $32.8 \pm 8.4$ & $29.4 \pm 8.0$ & 0.091 \\
\hline Education level (years) & $6.8 \pm 3 \cdot 3$ & $7.1 \pm 3.5$ & 0.261 \\
\hline $\begin{array}{l}\text { Marital status (\%) } \\
\text { Married } \\
\text { Single } \\
\end{array}$ & $\begin{array}{l}75 \cdot 75 \\
24.25\end{array}$ & $\begin{array}{l}71.82 \\
28.18\end{array}$ & 0.720 \\
\hline $\begin{array}{l}\text { Occupation (\%) } \\
\text { Housewife } \\
\text { Worker } \\
\text { Retired }\end{array}$ & $\begin{array}{c}56.91 \\
38.09 \\
5\end{array}$ & $\begin{array}{c}53.11 \\
40.68 \\
6.21\end{array}$ & 0.692 \\
\hline Hemoglobin $(\mathrm{g} / \mathrm{dl})$ & $10.6 \pm 1.1$ & $13.2 \pm 0.7$ & $<0.001^{*}$ \\
\hline Hematocrit (\%) & $33.9 \pm 3.4$ & $39.3 \pm 1.5$ & $<0.001^{*}$ \\
\hline $\mathrm{MCV}(\mathrm{fL})$ & $75.2 \pm 7.0$ & $88.2 \pm 4.1$ & $<0.001^{*}$ \\
\hline RDW (\%) & $16 \pm 2.4$ & $13 \cdot 3 \pm 1.1$ & $<0.001^{*}$ \\
\hline Serum iron $(\mathrm{mcg} / \mathrm{dl})$ & $33.8 \pm 15.4$ & $92.6 \pm 11.3$ & $<0.001^{*}$ \\
\hline TIBC (mcg/dl) & $454 \cdot 7 \pm 75 \cdot 5$ & $291.4 \pm 48.9$ & $<0.001^{*}$ \\
\hline Serum ferritin $(\mathrm{ng} / \mathrm{ml})$ & $8.2 \pm 7.4$ & $35.3 \pm 13.6$ & $<0.001^{*}$ \\
\hline $\begin{array}{l}\text { Digit Span } \\
\text { Total } \\
\text { Digit forward } \\
\text { Digit backward }\end{array}$ & $\begin{array}{l}7.1 \pm 2.5 \\
4.1 \pm 1.6 \\
3.0 \pm 1.1\end{array}$ & $\begin{array}{l}9.9 \pm 2.4 \\
5.8 \pm 1.7 \\
4.1 \pm 1.1\end{array}$ & $\begin{array}{l}<0.001^{*} \\
<0.001^{*} \\
<0.001^{*}\end{array}$ \\
\hline Digit Symbol & $31.8 \pm 15.8$ & $35.9 \pm 15.7$ & 0.293 \\
\hline HAQ-DI & $0.8 \pm 0.4$ & $0.1 \pm 0.3$ & $0.004^{*}$ \\
\hline BAI & $26.3 \pm 13.2$ & $16.4 \pm 12.5$ & $0.003^{*}$ \\
\hline BDI & $17.6 \pm 11.3$ & $10.5 \pm 8.2$ & $0.005^{*}$ \\
\hline $\begin{array}{l}\text { SF-36 PCS } \\
\text { SF-36 MCS }\end{array}$ & $\begin{array}{r}42.7 \pm 21.8 \\
49.6 \pm 22.5\end{array}$ & $\begin{array}{l}73.3 \pm 24.2 \\
69.4 \pm 22.4\end{array}$ & $\begin{array}{l}<0.001^{*} \\
0.001^{*}\end{array}$ \\
\hline Fatigue(VASmm) & $71.3 \pm 25.1$ & $32.5 \pm 27.5$ & $<0.001^{*}$ \\
\hline
\end{tabular}

IDA: iron deficiency group, MCV: mean corpuscular volume, RDW: red blood cell volume distribution width,

TIBC: total iron binding capacity, HAQ-DI: Health Assessment Questionnaire Disability Index,

BAI: Beck Anxiety Inventory, BDI: Beck Depression Inventory,

SF-36 PCS: Short Form-36 Physical Component Summary,

SF-36 MCS: Short Form-36 Mental Component Summary,

*: statistically significant difference

Infants and young children are at higher risk for IDA during their first 2 years of life." In this age group, IDA has been shown to cause disturbances in psychomotor development and cognitive functions. ${ }^{4,5}$ Women of reproductive age also have high rates of IDA because of pregnancy, menstruation and inadequate intake of iron. ${ }^{11}$ However, there are only a few studies to investigate the effects of IDA on cognitive functioning in women of reproductive age in the literature. ${ }^{1,2,20}$ Khedr et al. showed 
that subjects aged 16-28 years with IDA performed poorer on Digit forward, Digit backward and Digit Symbol tests than control subjects. ${ }^{2}$

Table 2. Pearson's correlation coefficients for the association between education, serum hemoglobin, iron, and ferritin levels and cognitive tests scores $(n=65)$

\begin{tabular}{|l|c|c|c|c|}
\hline & $\begin{array}{c}\text { Digit } \\
\text { Forward }\end{array}$ & $\begin{array}{c}\text { Digit } \\
\text { Backward }\end{array}$ & $\begin{array}{c}\text { Digit } \\
\text { SpanTotal }\end{array}$ & $\begin{array}{c}\text { Digit } \\
\text { Symbol }\end{array}$ \\
\hline Education & $0.58^{*}$ & $0.59^{*}$ & $0.55^{*}$ & $0.55^{*}$ \\
\hline Hemoglobin & $0.43^{*}$ & $0.44^{*}$ & $0.45^{*}$ & 0.19 \\
\hline Serum iron & $0.61^{*}$ & $0.56^{*}$ & $0.60^{*}$ & $0.35^{*}$ \\
\hline Serum ferritin & $0.27^{*}$ & $0.28^{*}$ & $0.24^{*}$ & 0.21 \\
\hline
\end{tabular}

*: statistically significant difference ( $\mathrm{p}<0.05)$

Murray-Kolb et al. showed that iron-sufficient women performed better on cognitive tests than IDA women who aged 18-35 years. ${ }^{1}$ Similar to these studies, we detected that women of reproductive age with IDA had lower scores of Digit Forward, Digit Backward and Digit Symbol tests than the women without IDA. The difference in Digit Symbol test scores was also found lower than that of the control group, but the difference did not reach level of significance. Similarly, Ukkirapandian et al. found no significant difference in Digit Symbol test scores between anemic young women and healthy young women. ${ }^{20}$ The different results in Digit Symbol test scores were attributed to the different sample size and education level of the study subjects. Education level of subjects has not been assessed in the previous studies. According to our results, IDA seems to cause different cognitive impairments not only in early stages of development, but also in adult life.

Table 3: Pearson's correlation coefficients for the association between education, serum hemoglobin, iron, and ferritin levels and clinical parameters $(\mathrm{n}=65)$

\begin{tabular}{|l|c|c|c|c|c|c|}
\hline & HAQ-DI & BAI & BDI & $\begin{array}{c}\text { SF-36 } \\
\text { PCS }\end{array}$ & $\begin{array}{c}\text { SF-36 } \\
\text { MCS }\end{array}$ & Fatigue \\
\hline Education & -0.16 & -0.15 & -0.04 & 0.14 & 0.15 & $-0.24^{*}$ \\
\hline Hemoglobin & $-0.25^{*}$ & $-0.31^{*}$ & $-0.29^{*}$ & $0.40^{*}$ & $0.38^{*}$ & $-0.42^{*}$ \\
\hline Serum iron & $-0.32^{*}$ & $-0.36^{*}$ & $-0.30^{*}$ & $0.51^{*}$ & $0.43^{*}$ & $-0.56^{*}$ \\
\hline Serum ferritin & $-0.28^{*}$ & $-0.28^{*}$ & $-0.29^{*}$ & $0.41^{*}$ & $0.35^{*}$ & $-0.40^{*}$ \\
\hline
\end{tabular}

HAQ-DI: Health Assessment Questionnaire Disability Index, BAI: Beck Anxiety Inventory, BDI: Beck Depression Inventory,

SF-36 PCS: Short Form-36 Physical Component Summary, SF-36 MCS: Short Form-36 Mental Component Summary,

*: statistically significant difference $(\mathrm{p}<0.05)$

In the present study, we found that cognitive performance had significant correlations with levels of education, hemoglobin, serum ferritin and serum iron in women of reproductive age. There is a substantial amount of variation in the results of previous studies in this field. ${ }^{1,2,11,21,22}$ In a similar vein to our study, Murray-Kolb et al. reported the relation of serum ferritin levels and cognitive performance in young adult women. ${ }^{1}$ Petranovic et al. reported that hemoglobin levels were significantly correlated with 
cognitive function in obese women aged between 25 and 42 years. ${ }^{22}$ In contrast, Fordy et al. showed no association between low ferritin levels and poor performance on Digit Span test in young males and females. ${ }^{21}$ Khedr et al. found no significant correlation between levels of hemoglobin and serum iron and scores of Digit Forward, Digit Backward, Digit Symbol tests, but found a significant correlation with Mini-Mental State Examination scores and intelligence. ${ }^{2}$ It is difficult to make a comparison of results as the different characteristics of study subjects and the different sample sizes. The previous studies did not investigate the relationship between education and cognition. ${ }^{11}$ This is the first study to evaluate the relationship between education and cognition and the results need to be confirmed in further studies.

Iron deficiency and IDA may cause some cognitive disfunctions, but it is unclear those disfunctions are the same. ${ }^{5}$ Some studies found a correlation between hemoglobin levels and cognitive function, while others found correlation between serum iron levels and cognitive function. ${ }^{1,5,7,23}$ In the present study, we found that both iron deficiency and IDA were related to poor cognitive performance. Sareen et al. did not found any correlation between cognitive performance and hemoglobin levels in females aged 1825 years. ${ }^{23}$ Similar to our results, Murray-Kolb et al. reported the relation of ferritin levels and cognitive performance and also a significant relationship between anemia and speed of processing in young adult women. In fact, both ID and IDA cause major changes in dopamine levels in certain brain areas and it is possible to obtain a clear idea that ID and IDA appear to affect cognitive performance. 5

Nutritional deficiencies especially iron deficiency anemia can affect the psychological state and brain mechanisms that can lead to anxiety disorders and mood disorders such as depression. Reduced muscle strength and fatigue are commonly associated with anemia and may have detrimental effects on quality of life, therefore anemia facilitates the development of anxiety and depressive symptoms. On the other hand, the data are quite limited for anxiety and depression. ${ }^{9}$ In the present study, we found that anxiety and depression scores were significantly higher in IDA group than that of the normal subjects. Correlatively to our study, Semiz et al. reported that anxiety and depression scores were significantly higher in young adult patients with IDA than the controls. ${ }^{24}$ We also found that the levels of serum iron, ferritin, and hemoglobin had moderate negative correlation with scores of depression and anxiety in women with reproductive age. Similarly, Noorazar et al. found a significant correlation between depressive symptoms and hemoglobin levels. ${ }^{9}$

Fatigue is one of the most common symptoms of IDA. While IDA is known to be associated with fatigue, there is stil an inadequate evidence of such an association in women with reproductive age. ${ }^{10,11,25}$ Patterson et al. showed that self-reported fatigue was significantly higher in women aged $18-50$ years with iron deficiency. ${ }^{25}$ In the other study, Patterson et al. also showed that the total fatigue score was significantly higher in women aged $18-50$ years with iron deficiency. ${ }^{10}$ Similar to the results of these studies, we detected that level of fatigue was increased in IDA group compared to controls. We also detected that education, levels of serum iron, ferritin, and hemoglobin levels were significantly associated with fatigue.

There is evidence that iron plays an essential role in the optimal functioning of skeletal muscles. Iron is present in slow red fibers in muscles and is responsible for oxygen storage in myoglobin. ${ }^{26}$ We assessed physical functioning of the subjects using HAQ- 
DI. Physical functioning in women with IDA was worse than the controls. In addition, serum iron, ferritin, and hemoglobin levels were found to be correlated with physical functioning. To our knowledge, there is no study to evaluate the physical function using a specific assessment tool in subjects with IDA.

There is a widely belief that IDA has effects on quality of life and chronic fatigue. Only a few studies in the literature investigated this belief. ${ }^{10,25}$ In the present study, physical and mental health of adult women with IDA were found to be significantly impaired in comparison to controls. In correlation analysis, we detected that serum iron, ferritin, and hemoglobin levels were significantly correlated with both physical and mental health quality. Correlatively to our results, Rangan et al. detected that anemic subjects scored significantly impaired on the General Health Questionnaire (mental health assessment) than non-anemic subjects. ${ }^{27}$ Patterson et al. reported that physical and mental health were significantly impaired in women aged 18-50 years with ID. ${ }^{25}$ In another study, Patterson et al. reported that while mental health scores were significantly lower in women 18 to 50 years of age in ID group, no significant difference in physical health scores were found. ${ }^{10}$ These results indicate that adult women with ID or IDA have limitations on general health and decreased health quality. As iron is an important component of many enzymes involved in cellular energy metabolism and neurotransmitter synthesis, inadequate energy production and alterations in neurotransmitter metabolism may be the underlying mechanisms of decreased quality of life. ${ }^{10,25}$

This study had some limitations. First, we did not evaluate the effects of iron supplementation on cognition. Several studies detected an association between iron supplementation and cognitive improvement. ${ }^{10,25}$ Second, we did not assess irondeficient women without anemia. Iron deficiency and IDA may have different effects on cognitive functions. Third, only female subjects were recruited for the study. However, it seems that there are not any substantial different effects of IDA on cognitive functions depending on the sex. ${ }^{5}$

In conclusion, this study demonstrated that IDA negatively affects cognition, physical functioning, quality of life, fatigue, and symptoms of anxiety and depression in reproductive-age women. Early detection and treatment of IDA is essential to prevent cognitive impairment and to improve quality of life in adult women. Further studies with a larger sample size are needed to replicate the results of this study in women of reproductive age.

\section{References}

1. Murray-Kolb L.E, Beard JL. Iron treatment normalizes cognitive functioning in young women. Am J Clin Nutr 2007;85:778-87.

2. Khedr E, Hamed SA, Elbeih E, El-Shereef H, Ahmad Y, Ahmed S. Iron states and cognitive abilities in young adults: neuropsychological and neurophysiological assessment. Eur Arch Psychiatry Clin Neurosci 2008;258:489-96.

3. Pollitt E. Iron deficiency and cognitive function. Annu Rev Nut 1993;13:521-37.

4. Parmar BJ. Iron deficiency: beyond anemia. Acad J Ped Neonatol 2016;2:1-4.

5. Jauregui-Lobera I. Iron deficiency and cognitive functions. Neuropsychiatr Dis Treat 2014;10:2087-95.

6. Elwood PC, Hughes D. Clinical trial of iron therapy on psychomotor function in anemic women. British Med J 1970;3:254-5. 
7. Patterson AJ. Iron deficiency in Australian women: development, implications and treatment. $\mathrm{PhD}$ Thesis, 1999, University of Newcastle, NSW.

8. Chellappa AR, Karunanidhi S. Effect of iron and zinc supplementation on cognitive functions of female adolescents in Chennai, India. International Conference on Nutrition and Food Sciences IPCBEE 2012;39:17-24.

9. Noorazar SG, Ranjbar F, Nemati N, Yasamineh N, Kalejahi P. Relationship between severity of depression symptoms and iron deficiency anemia in women with major depressive disorder. Anal Res Clin Med 2015;3:219-24.

10. Patterson A, Brown WJ, Roberts DCK. Dietary and supplement treatment of iron deficiency results in improvements in general health and fatigue in Australian women of childbearing age. J Am Coll Nutr 2001;20:337-42.

11. Greig AJ, Patterson AJ, Collins CE, Chalmers KA. Iron deficiency, cognition, mental health and fatigue in women of childbearing age: a systematic review. J Nutr Sci 2013;2:1-14.

12. Joy S, Kaplan E, Fein D. Speed and memory in the WAIS-III Digit Symbol-coding subtest across the adult lifespan. Arch Clin Neuropsychol 2004;19:759-67.

13. Savașir I, Şahin N. WISC uyarlamaçalıșmalarıönrapor -I. Turk J Psychol 1978;1:33-7.

14. Kucukdeveci AA, Sahin H, Ataman S, Griffiths B, Tennant A. Issues in cross-cultural validity: example from the adaptation, reliability, and validity testing of a Turkish version of the Stanford Health Assessment Questionnaire. Arth Rheum 2004;51:14-9.

15. Pinar R. Reliability and construct validity of the SF-36 in Turkish cancer patients. Qual Life Res 2005;14:259-64.

16. Hisli N. Beck Depression Inventory for university students on the validity and reliability. Psikoloji Dergisi 1989;7:3-13.

17. Ulusoy M, Sahin NH, Erkmen H. Turkish version of the Beck Anxiety Inventory: psychometric properties. J Cogn Psychother 1998;12:163-72.

18. Feise RJ, Menke JM. Functional Rating Index: a new valid and reliable instrument to measure the magnitude of clinical change in spinal conditions. Spine 2001;26:78-87.

19. Moos T, Rosengren Nielsen T, Skjorringe T, Morgan EH. Iron trafficking inside the brain. J Neurochem 2007;103:1730-40.

2o. Ukkirapandian K, Natarajan N, Prassanaraghavan K, Mohan P, Selvam L. A clinical study on effects of iron deficiency anemia on cognitive function among undergraduate paramedical students. Int J Med Sci Public Health 2014;3:948-50.

21. Fordy J, Benton D. Does low iron status influence psychological functioning? J Hum Nutr Diet 1994;7:127-33.

22. Petranovic D, Batinac T, Petranovic D, Ruzic A, Ruzic T. Iron deficiency anemia influences cognitive functions. Med Hypotheses 2008;70:70-2.

23. Sareen M, Sareen S, Khajuria S, Roy S. Impact of iron levels on cognitive functioning among dental students of Udaipur, Rajasthan (India). F10oo Research 2012;1:54.

24. Semiz M, Uslu A, Korkmaz S et al. Assessment of subjective sleep quality in iron deficiency anemia. Afr Health Sci 2015;15:621-7.

25. Patterson AJ, Brown WJ, Powers JR, Roberts DCK. Iron deficiency, general health and fatigue: results from the Australian Longitudinal Study on Women's Health. Qual Life Res 2000;9:491-7.

26. Stugiewicz M, Tkaczyszyn M, Kasztura M, Banasiak W, Ponikowski P, Jankowska EA. The influence of iron deficiency on the functioning of skeletal muscles: experimental evidence and clinical implications. Eur J Heart Fail 2016;18:762-73.

27. Rangan AM, Blight GD, Binns CW. Iron Status and Non-Specific Symptoms of Female Students. J Am Coll Nutr 1998;17:351-5. 